\title{
Forholdet Iran-USA er gidsel for magtkamp i Teheran
}

Ali Alfoneh

\section{Magtkamp mellem præsidenten og Revolutions- garden truer afspændingen med USA. Det samme gør Khameneis frygt for Rouhanis popularitet og mulighed for at udfordre den $\varnothing$ verste Leders magtposition}

'Historisk', lød dommen over præsidenterne Barack Obama og Hassan Rouhanis telefonsamtale - den første af sin slags siden Irans islamiske revolution i 1979 - under FN's Generalforsamling i New York den 28. september 2013. Samtalen, som var kommet i stand i kølvandet på længere tids hemmeligt diplomati, er siden blevet fulgt op af nye forhandlinger om Irans kontroversielle atomprogram, samt Obama-administrationens energiske forsøg på at forbedre relationerne til Den Islamiske Republik.

Obamas nye Iran-initiativ sammenlignes ofte med Præsident Richard Nixons åbning over for Kina i 1970'erne, og ikke uden grund. Ved at normalisere relationerne til Folkerepublikken Kina formåede Ni- xon at udnytte rivaliseringen mellem Sovjetunionen og Folkerepublikken Kina. Normalisering af relationerne til Iran kan sikre den mellemøstlige magtbalance mellem Iran, Saudi-Arabien og Israel, ganske som trekantsdiplomatiet sikrede magtbalancen under Den Kolde Krig, argumenterer fortalerne for denne politik.

Imidlertid er der, lighederne til trods, også fundamentale forskelle mellem Mao Zedongs Kina og Den Islamiske Republik Iran: Folkerepublikken Kina var en atommagt forud for normalisering af relationerne til USA, mens Iran efter alt at dømme er en aspirerende atommagt, hvilket vil udgøre et bestandigt irritationsmoment Teheran og Washington imellem. Maos åbning 
over for USA markerede et strategisk skifte i den kinesiske topledelses udenrigs- og sikkerhedspolitik, mens Irans Øverste Leder Ayatollah Ali Khamenei vedvarende understreger, at Irans åbning over for USA er 'heroisk fleksibilitet' eller med andre ord en taktisk manøvre.

Vigtigst af alt formåede Mao gennem kulturrevolutionen at rense ud blandt potentielle kritikere forud for åbningen over for Washington, mens Den Islamiske Republik er et polycentrisk politisk system med Khamenei som primus inter pares.

\section{Iran polariseres}

Det sidste forhold udgør den alvorligste trussel mod forbedring af de iransk-amerikanske relationer. Alt imens Obama-administrationen forbereder normalisering af relationerne til Iran, polariseres Irans indenrigspolitik. Konflikten er personificeret af præsident Hassan Rouhani og generalmajor Mohammad-Ali (Aziz) Jafari, Revolutionsgardens øverstbefalende. Modpolerne i iransk politik strides om, hvorvidt Iran skal være en status-quo-magt eller revisionistisk, systembevarende eller revolutionær, pragmatisk eller ideologisk? Mens Rouhani er fortaler for det første, gør Jafari og Revolutionsgardens officerskorps sig til talsmænd for det sidste og holder relationerne til USA som gidsel i den indenrigspolitiske magtkamp.

Forskellen mellem Rouhani og Ja- faris syn på USA er ikke uden relation til striden om magten i Iran: Hvis Rouhani kan normalisere relationerne til USA, kan han ikke blot cementere sin magtposition i Iran, men han kan også bruge afspænding i forholdet til USA som endnu et instrument til at underkaste Revolutionsgarden civil kontrol. Omvendt har Revolutionsgarden en iboende interesse $i$ at opretholde illusionen om Iran som et land under amerikansk belejring for derved at legitimere sin aktive intervention i Den Islamiske Republiks politiske og økonomiske liv samt sikre, at garden forbliver hævet over civil kontrol.

Stridens udfald er umuligt at forudse. Khamenei har hidtil støttet Rouhani for at balancere Revolutionsgarden, hvis magt voksede uforholdsmæssigt under Rouhanis forgænger som præsident, Mahmoud Ahmadinejad. Imidlertid kan Khamenei tænkes at fjerne sin støtte til præsidenten, hvis Rouhanis magtbase vokser sig så stor, at han kan udfordre Khamenei selv eller for alvor udfordre regimets revolutionære og ideologiske natur.

\section{Rouhani renser ud}

Efter annonceringen af valgresultatet spurgte en journalist fra dagbladet Iran Rouhani, om den nyvalgte præsident $\varnothing n s k e d e$ at "meje den nuværende regerings folk ned" fra deres offentlige embeder, hvortil Rou- 
hani svarede: "Jeg er kommet med en nøgle (Rouhanis kampagnesymbol) og ikke en segl!" Imidlertid fortsatte Rouhani til sine tilhængeres jubel: "Jeg har dog intet ansvar over for dem, som kom ind i regeringen uden gyldig billet!"

Efterhånden som offentligheden blev bekendt med Rouhanis udnævnelser til regeringen og generalguvernører, har kritikerne beskyldt ham for at bruge mejetærsker for at udrense den udøvende magt for politiske modstandere!

På lige fod med sin forgænger udnævnte Rouhani atten ministre, men med undtagelse af Hojjat alEslam Mostafa Pour-Mohammadi, justitsminister, er der ingen 'overlevende' fra Ahmadinejads regering.

Ti ud af Rouhanis atten ministre er erfarne teknokrater, som tidligere har tjent præsident Ali-Akbar Hashemi Rafsanjani. Regeringen tæller også to gejstlige: Hojjat al-Eslam Mahmoud Alavi, minister for statssikkerhed og efterretningsanliggender, samt Mostafa Pour-Mohammadi, justitsminister, som har en fortid som chef for udenrigsspionage ved Ministeriet for Statssikkerhed og Efterretningsanliggender.

Andre forhenværende efterretningsfolk tæller Ali Rabi’i, også kendt som 'Ebad', minister for kollektive virksomheder, arbejde og velfærd; Hamid Chitchian, energiminister; samt Abd al-Reza Rahman Fazli, indenrigsminister. Dette er det højeste antal forhenværende efter- retningsfolk i regeringen siden 1980.

Anderledes forholder det sig med Revolutionsgardens veteraner. Modsat Ahmadinejad-regeringerne, hvor over halvdelen af ministrene var revolutionsgardister, udnævnte Rouhani blot fire veteraner fra Revolutionsgarden: Mahmoud Hojjati, landbrugsminister; Ali Jannati, minister for kultur og islamisk propaganda; Reza Faraji, videnskabsminister; samt Hossein Dehqan, forsvarsminister. Dehqan er ikke blot den mest prominente revolutionsgardist i regeringen, han er også den eneste, som endnu har organisatoriske relationer til garden.

Rouhanis udnævnelse af generalguvernører følger samme strømning. Iran er administrativt inddelt i en og tredive provinser. Generalguvernøren, som udnævnes af præsidenten, er den højeste repræsentant for centralmagten i provinsen og nyder store magtbeføjelser. Rouhani har ikke blot udrenset samtlige generalguvernører som var udnævnt af sin forgænger, han har også systematisk udskiftet veteraner fra Revolutionsgarden med teknokrater. De eneste tilbageværende revolutionsgardister er generalguvernørerne i Øst Aserbajdsjan, Syd Khorasan, Zanjan og Kerman.

\section{Økonomisk krig}

Rouhanis angreb mod Revolutionsgarden begrænser sig ikke kun til 
politiske udnævnelser. Den nytiltrådte præsident fører også økonomisk krig mod Revolutionsgarden, som siden afslutningen af den otte år lange krig mod Irak (1980-1988) har udviklet sig til en hovedaktør i Irans økonomi.

Det var frygten for social uro i kølvandet på hjemsendelse af en kvart million frontfrivillige i 1988, som fik civile politikere til at overlade genopbygningen af Iran efter krigens ødelæggelser til Revolutionsgardens ingeniørkorps, som omdøbtes Khatam al-Anbia Genopbygningsbase.

Revolutionsgardens medlemmer, som havde været med til at grave skyttegrave langs den irakiske grænse, blev nu beordret til at udbygge Irans infrastruktur. Samtlige større offentlige projekter, herunder byggeri af dæmninger, udvidelse af havneanlæg, motorvejsbyggeri, blev overdraget til Revolutionsgarden uden licitation og udbudsrunder, hvilket hjalp garden med at akkumulere milliarder af dollar i dens finansielle institutioner. Under Ahmadinejad brugte Revolutionsgarden de opsparede midler til at købe statsejede virksomheder som Ahmadinejadregeringen privatiserede.

I sin første tale til Revolutionsgardens ledelse forlangte Rouhani, at Revolutionsgarden skulle holde sig hævet over partipolitiske skel og bør 'tilhøre hele folket', men forsikrede til gengæld, at den iranske stat ville fortsat gøre brug af gardens potentiale til udvikling af Irans økonomi.
Imidlertid viser den efterfølgende udvikling, at Rouhani gjorde gode miner til slet spil.

I første omgang rettede Rouhanis proxyer skytset mod Ahmadinejads projekter. Ahmadinejad havde for vane at indvie endnu uafsluttede projekter, som for eksempel den femtende og sekstende faser af South Pars gas- og oliefeltet, som ved indvielse manglede såvel pipelines, platforme, brønde samt raffinaderier! Imidlertid var Khatam al-Anbia Genopbygningsbase, der som entreprenør stod for færdiggørelse af projektet, angribernes reelle mål.

(For en gennemgang af Khatam al-Anbias aktiviteter se Ali Alfoneh: "How Intertwined is the Revolutionary Guards in Iran's Economy?" Middle Eastern Outlook. Washington DC: American Enterprise Institute, October 22, 2007, på http://www.aei.org/outlook/foreign-and-defense-policy/regional/ middle-east-and-north-africa/howintertwined-are-the-revolutionaryguards-in-irans-economy)

Angrebets anden runde indledtes af Ahmad Tavakoli, parlamentariker, som anklagede Revolutionsgarden for at udkonkurrere den private sektor på ulige vilkår. Tavakoli forlangte regeringsindgreb for at hjælpe den private sektor.

Rouhani-regeringen har også annulleret en større kontrakt om vejbyggeri med Khatam al-Anbia, annulleret en oliekontrakt på 30 mio. euro med samme entreprenør, samt 
tvunget Revolutionsgarden til uden betaling - at overdrage ejerskabet af Iran Marine Industrial Company (Sadra) til staten.

\section{Revolutionsgardens svar}

Revolutionsgardens ledelse svarede Rouhanis vedvarende angreb mod officerskorpsets politiske indflydelse og økonomiske interesser ved at lancere modangreb mod den nye præsidents akilleshæl: Udenrigs- og sikkerhedspolitikken generelt, samt åbningen over for USA i atomforhandlingerne i særdeleshed.

Det første slag om Irans udenrigsog sikkerhedspolitiske orientering mellem Rouhani og Revolutionsgarden udspillede sig efter Ayatollah Ali-Akbar Hashemi Rafsanjanis fordømmelse af Bashar al-Assad regimets brug af kemiske våben mod egen befolkning.

Rouhani brugte sin mentor til at sende signalet om Irans vilje til at forhandle om Syriens fremtid med USA. Revolutionsgarden svarede ved at sende ledende officerer som brigadegeneral Hossein Salami, gardens næstkommanderende, og generalmajor Qassem Suleimani, kommandør for Quds-styrken, der som gardens enhed for ekstraterritoriale operationer er engageret i forsvaret af det syriske regime, til pressemøder for offentligt at erklære gardens støtte til Assad-regimet. Garden noterede sig en sejr, da Hensigtsmæssighedens Råd måtte tilbagekalde sin formand, Rafsanjanis udtalelser.

Revolutionsgarden åbnede en ny front mod Rouhani i forbindelse med dennes rejse til New York i anledning af FN's Generalforsamling. Generalmajor Jafari fordømte Rouhanis telefonsamtale med Obama som 'en taktisk fejl', og gardens andre fremtrædende officerer rettede skytset mod USA og præsident Obamas tale ved Generalforsamlingen.

Angrebene havde ikke blot til hensigt at sabotere afspændingen mellem Teheran og Washington, men tjente først og fremmest det formål at frarøve Rouhani en betydelig udenrigspolitisk sejr.

Efterhånden som Revolutionsgardens slagsmål med Rouhani-regeringen tog til i styrke, fremførte Khamenei sin tese om 'heroisk fleksibilitet' i atomforhandlingerne, forsvarede Rouhani-regeringens atomforhandlere, samt befalede Revolutionsgarden til ikke at blande sig i politik.

Nogle få dage efter kvitterede brigadegeneral Hossein Salami, Revolutionsgardens næstkommanderende, med at understrege, at han ingen plads har for fleksibilitet i sin strategi. Den 10. december svarede Revolutionsgardens øverstbefalende Khameneis befaling om, at Revolutionsgarden ikke skal blande sig i politik:

"Der er dem, som skaber en stemning om, at garden er en militær [organisation], som ikke må blande sig i politik og bruger Hans Hellig- 


\section{BAGGRUND}

hed Imamens ord imod os. Vi ignorerer sådanne folk og gør vort arbejde. Vi kan ikke afstå fra dette [indblanding i politik]... Hvis vi tror, at militært beredskab alene er nok til at bevare revolutionen, og de interne fjender, med udlandets støtte, vil tage revolutionen fra os ad politiske veje, har vi tabt alt. I så fald har vi ikke levet op til vores pligt."

På den økonomiske front svarede Revolutionsgarden ved at myrde Safdar Rahmatabadi, viceminister for industri og handel, den 10. november 2013. Det var Rahmatabadi som havde beordret Revolutionsgarden at tilbagelevere SADRA-selskabet til staten.

\section{Skrøbelig afspænding}

Det er denne indenrigspolitiske dynamik, som kaster lange skygger over udsigten til afspænding mellem Iran og USA samt planer om normalisering af relationerne de to stater imellem. Khameneis frygt for Rouhanis popularitet og den nyvalgte præsidents potentiale til at udfordre hans magtposition bidrager yderligere til hele projektets skrøbelighed.

Obama-administrationen er næppe totalt uvidende om den indenrigspolitiske situation i Iran, og har også selv måttet forsvare sig mod indenrigspolitisk kritik af åbningen over for Den Islamiske Republik. Imidlertid begår Obama-administra- tionen en klassisk fejl: I forsøget på at oprette tilliden til Teheran har Washington lempet sanktionsregimet mod Den Islamiske Republik. Derved afskriver Obama-administrationen sig det instrument som i første omgang fik Khamenei til at anerkende Rouhanis valgsejr og fremstamme ordene 'heroisk fleksibilitet'.

Også derfor er det højest tvivlsomt, om Obama-administrationen formår at gøre Nixon kunsten efter.

Ali Alfoneh er senior fellow ved Foundation for Defense of Democracies $i$ Washington som topekspert om Iran. Forfatter til bogen 'Iran Unveiled: How the Revolutionary Guards Is Transforming Iran from Theocracy into Military Dictatorship'. AEI Press, April 2013. Voksede op $i$ Teheran, men flyttede med familien til Danmark i 1988 og tog en universitetsgrad i politologi. Medlem af Herlev byråd 1994 til 1998, lektor i politisk фkonomi Syddansk Universitet 2003 til 2004 og forsker ved Forsvarsakademiets Institut for Strategi fra 2004 til 2006.

For en gennemgang af Revolutionsgardens finansielle aktiviteter se Ali Alfoneh: "The Revolutionary Guards' Looting of Iran's Economy." Middle Eastern Outlook. Washington DC: American Enterprise Institute, June 23, 2010, på http://www.aei.org/article/foreign-anddefense-policy/regional/middle-east-andnorth-africa/the-revolutionary-guardslooting-of-irans-economy/ 